\title{
STRATEGIC ENVIRONMENTAL ASSESSMENT POLICY OF CIREBON COASTAL AREA FOR SUSTAINABLE DEVELOPMENT ${ }^{\Omega}$
}

\author{
Endang Sutrisno and Ria Apriani \\ Master of Law Study Program, Universitas Swadaya Gunung Jati Cirebon, Indonesia \\ E-mail: endangsutrisno94@gmail.com
}

\begin{abstract}
Government policy relies on the balance of economic and environmental conservation activities to achieve sustainable development. In the perspective of legal studies, this study employs normative legal research and empirical legal research methods, particularly descriptive analysis and qualitative analysis method. Cirebon City does not have a Strategic Environmental Assessment regarding coastal development management policy due to lack of Human Resources, institutional and budgetary constraints. Conservation activities are required to maintain the diversity of aquatic biota through habitat rehabilitation as well as flora and fauna preservation. Therefore, potential excavation, potential zone arrangement and formulation concept of coastal zone and small islands management system are conducted through arranging Strategic Environmental Assessment. This is are crucial considering the current condition of Cirebon City's Coast along 7 (seven) kilometers. Approximately $20 \%$ of the coast suffer severe damage. This damage occurs due to people's behavior who cut down the mangrove trees for their daily needs.
\end{abstract}

Keywords: strategic environmental assessment, conservation

\begin{abstract}
Abstrak
Kebijakan pemerintah berpijak pada keseimbangan aktivitas ekonomi dan konservasi lingkungan untuk mewujudkan pembangunan berkelanjutan. Dalam perspektif kajian hukum, penelitian ini menggunakan metode penelitian hukum normatif dan penelitian hukum empiris, dengan spesifikasi deskriptif analisis dan metode analisis kualitatif. Kota Cirebon tidak memiliki Kajian Lingkungan Hidup Strategis berkenaan dengan kebijakan pengelolaan pembangunan kawasan pantai, disebabkan kurangnya Sumber Daya Manusia, keterbatasan kelembagaan dan anggaran. Aktivitas konservasi diperlukan untuk mempertahankan keragaman biota air melalui tindakan rehabilitasi habitat, perlindungan flora dan fauna. Untuk itu, dilakukan upaya penggalian potensi, penyusunan zona potensi dan perumusan konsep sistem pengelolaan zona pesisir dan pulau-pulau kecil melalui pengaturan Kajian Lingkungan Hidup Strategis. Hal ini sangat penting mengingat kondisi Pantai Kota Cirebon sepanjang 7 (tujuh) kilometer saat ini dalam kondisi memperihatinkan. Sekitar 20\% mengalami kerusakan yang cukup parah. Kerusakan ini terjadi karena perilaku masyarakat yang justru menebangi pohon bakau untuk kebutuhan mereka sehari-hari.
\end{abstract}

Kata Kunci: kajian lingkungan hidup strategis, konservasi

\section{Introduction}

Law Number 32 Year 2009 on Preservation and Management of Environment mandated that government and local government are obliged to implement Strategic Environmental Assessment in organizing or evaluating some documents including Spatial Plans (RTRW) with its details, Long Term Development Plan (RPJP),

$\Omega$ This scientific article is the research result of Magister Program of Universitas Swadaya Gunung Jati Cirebon with Contract Number 224/Pascasarjana/XII/2016.
Medium Term National, Provincial, and Regency/City Development Plan (RPJM), also policy, planning, and/or potential program that potentially bring impacts and/or risks to the environment regulated in Article 15 Law Number 32 Year 2009. Strategic Environmental Assessment is basically an environmental management instrument which is mandatory. This is the form of obligation that must be conducted by policy maker, planner and programmer. The position of KLHS is as the basis in formulating the policy, 
plan and or development program in certain area in order to ensure that the principle of sustainable development has become the foundation and it has been already integrated for development in certain regions. Strategic Environmental Assessment contains some studies such as supporting capacity and accommodating capacity of environment for development, estimation of environmental impacts and risks, service performance/ecosystem service, efficient use of natural resources, the degree of vulnerability and adaptation capacity toward climate change and the level of endurance and biodiversity potentials. All of them are regulated in Article 15 paragraph (1), Article 17 paragraph (1) and Article 16 of Law Number 32 Year 2009 on Environment Preservation and Management.

Besides, the existence of law about conservation of biological resources (Law Number 5 Year 1999 on Conservation of Biological Resources and Ecosystem) is insufficient to support conservation in coastal area in which its effecttiveness should be able to synergize with management regulation of coastal area itself in Law Number 1 Year 2004 on Amendment on Law Number 27 Year 2007 on Management of Coastal Area and Small Islands. The coastal area issues obviously cause social problems; the government should be duly filled-oriented to development based on local resources such as agriculture, forestry, marine and fisheries. ${ }^{1}$ Therefore, the social problems must be exceptionally handled by law as well as tremendous work. ${ }^{2}$ The turning point of this thought starts from the commitment of state of law that all activities of the State should be based on law. ${ }^{3}$ Moreover, there are four conditions of law model: first, repressive colonial model of law; second, deve-

1 Endang Sutrisno and Esmi Warassih, "Harmonization of Fisheries Law for Fishermen Empowerment in Indonesia", South East Asia Journal of Contemporary Business, Economics and Law, Vol.11 Issue 4, December 2016, p. 45.

2 Endang Sutrisno, "Implementasi Pengelolaan Sumberdaya Pesisir Berbasis Pengelolaan Wilayah Pesisir Secara Terpadu Untuk Kesejahteraan Nelayan", Jurnal Dinamika Hukum, Vol. 14 No. 1, 2014, p. 3.

3 Rahman Yasin, "Telaah Putusan MK dalam Sengketa PH PU Pilpres 2004 (Perspektif Negara Demokrasi Konstitusional)", Jurnal Konstitusi, Vol. 11 No. 4, December 2014, p. 652. lopmental model of law; third, progressive model of law; and fourth, integrative model of law. ${ }^{4}$

The character of Cirebon City as a coastal city is characterized by relatively high siltation in coastal area, resulting in the emergence of arising land. This has affected the large of the administration area of Cirebon City which is estimated to have reached +75 hectares spread in 6 (six) villages: Panjunan, Kasepuhan, Lemahwungkuk, Pegambiran, Kesenden, and Kebonbaru.

In regard to the effort of realizing an effective legal system, it is necessary to reorganize the legal institution supported by increasing quality of human resources and culture as well as legal awareness of the people, along with the renewal of harmoniously structured legal material without conflict and overlap; moreover, the law is continually updated in accordance with the demand of necessity development. ${ }^{5}$ Sectors of life governed by the rule of law must be able to reach the point of order and a sense of justice including economic management, human resources and natural resources in order to achieve happiness together. ${ }^{6}$

It is significant to realize that to create legal justice takes an active role from various parties and it can be from either formation of legal products or the enforcement of legal products. ${ }^{7}$ It has been well comprehended since the development of law in this country tends to move aimlessly artificial space. ${ }^{8}$ Indonesia today confronts a very "unique" problem of law per-

4 Romli Atmasasmita, "Tiga Paradigma Hukum dalam Pembangunan Nasional”, Jurnal Hukum Prioris, Vol. 3 No. 1, 2012, p. 5.

5 Bahria Prentha, "Filsafat Hukum dan Nilai-Nilai Pancasila", Jurnal Ilmiah Kebijakan Hukum, Vol. 5 No. 2, August 2011, p. 177.

6 Endang Sutrisno-Sudarminto, "Legal Culture of Fisherman Communities in Indonesia (Studies in Cirebon Coastal Fishing Communities in the Northern Coast of West Java, Indonesia)", International Journal of Current Advanced Research, Vol. 6 Issue 2, February 2017, p. 2249.

7 Yunus Bureni, "Moralitas Pembentukan Peraturan Daerah dalam Upaya Mencapai Keadilan Substantif (Morality Formation of Local Regulations in An Effort to Ensure Substantive Justice)", Jurnal Legislasi Indonesia, Vol. 10 No. 2, June 2013, p.125.

8 Dayanto, "Rekonstruksi Paradigma Pembangunan Negara Hukum Indonesia Berbasis Pancasila", Jurnal Dinamika Hukum, Vol. 13 No. 3, September 2013, p. 498. 
formance regarding the formal truth treated as the most dominant consideration of legal decision embracing reine Rechtslehre Kelsenian's way of thinking. An approach that is still in further discussion through a more holistic alternative paradigm. ${ }^{9}$ Considering monistic positivism law, it only recognizes one kind of justice born from positive law. ${ }^{10}$

The reality of the approach to the study of the legal order in the description above could be used as a further understanding to examine the case of development policy that has been applied so far. It is more oriented to the development of the land sector than the coastal and the marine areas. In order to achieve a balance of regional development, the coastal area and small islands need to be pushed faster; thus, it can minimize the existing gap.

Moving from the characteristics of the location and potentials of the coastal area and small islands where the various needs of the community usually comes from marine and land resources, automatically coastal and small islands communities sustain their needs by utilizing the given resources in the region. The mangrove logging activities, irregular and uncontrolled use of the tread charts and the utilization of other coastal and marine resources are sources of considerable pressure from the community. Significant negative impacts have been experinced including the seriously threatened quality and quantity of aquatic biota diversity in the region. The rationalization between benefits and conservation cannot be realized as a result of social economic activity pressure. In addition to the threat of biodiversity, there are physical problems, such as contamination and coastal abrasion. Hence, habitat and resource destruction occurring in coastal area and small islands should be taken intensely by all parties. The problem concerns how the policy of Stra-

9 Endang Sutrisno, "Tracing the Performance of Law in Indonesia (A Perspective of Thomas Kuhn's "Normal Science", Journal of Law, Policy and Globalization", Vol. 37, 2015, p. 126.

10 Ibnu Artadi, "Dekonstruksi Pemahaman Penyelesaian Sengketa Bisnis (Ekonomi dan Keuangan) Beraspek Pidana melalui Prosedur Perdamaian: Menuju Proses Peradilan Pidana Rekonsiliatif", Jurnal Hukum Responsif, Vol. 1 No. 1, 2011, p. 33-34. tegic Environmental Assessment in coastal area of Cirebon City to realize sustainable development based on Law Number 32 Year 2009 on Preservation and Management of Environment.

\section{Research Methods}

The approach method applied normative legal research by reviewing and analyzing aspect of legislation in relation with the enforcement of Law Number 32 Year 2009 on Preservation and Management of Environment and Law Number 1 Year 2014 on Amendment of Law Number 27 Year 2007 on Management of Coastal Area and Small Islands. It reviewed legal content as a necessity (das sollen) in the form of written rules that apply to the normative provisions on the Strategic Environmental Assessment which overlap with the concept of sustainable development. Normative legal research is a scientific research procedure to find the truth based on the logic of legal studies from the normative perspective, namely the science of law of which object is the law itself ${ }^{11}$. This study also employed empirical-juridical approach with the enforcement of the legal norm of Law Number 32 Year 2009 on Preservation and Management of Environment with a focus on stakeholder behavior to formulate a Strategic Environmental Assessment policy, which is outlined in the policy product of the Coastal Zone and Small Island Zoning Policy Year 2013. The emphasis of this approach has a tendency to legal research with subgroup studies of law as a dynamic conflict process with subgroups of legal compliance and effectiveness, stratification and effectiveness of legal sanctions, legislation process: between regulation and deregulation. ${ }^{12}$ This study was further described and analyzed using given legal theory in the perspective of Environmental Law by focusing on the study area at Cirebon City's Coast in the context of a basic understanding through das Sein. It is vital because the approach of regulat-ory substance regarding the Strategic Environmental Assessment in dynamics of urban development beco-

\footnotetext{
11 Johnny Ibrahim, 2006, Teori dan Metodologi Penelitian Hukum Normatif, Malang: Bayumedia Publishing, p. 57.

12 Ibid., p. 35
} 
mes crucial due to the great influence of power of economic energy on policy making by Local Government.

\section{Discussion}

Strategic Environmental Assessment in the Development of Coastal Area of Cirebon City

A public policy should always be under a supervision or control, which is called as policy evaluation. The evaluation usually aims to measure how effective the public policy is and to ensure its accountability to the constituent as well as how far the goal of the policy reached. This evaluation is necessary to see the discrepancy between expectation and reality. ${ }^{13}$

The problems of public policy have definitely related to the legal matter. Law as legislation, the law is in the form of the legislation; product policy should be understood in its realization in all jurisdictions and in all steps is supposed to be an entity that is authentic. ${ }^{14}$

According to Article 15 section 5 of Law Number 32 Year 2009 on Preservation and Management of Environmet, the government and regional government are required to create Strategic Environmental Assessment to ensure that the principle of sustainable development has been the basic and integrated in the development of region and/or the policy, planning, and/or program for arranging or evaluating Spatial Plan and its details, Long Term Development Plan, Medium Term National, Provincial and Regency/City Development Plan and other policy, planning, and or program which are potential to cause environmental impacts. According to this law, KLHS basically is an environmental management instrument which is mandatory. This is the form of obligation that must be conducted by policy maker, planner and programmer. It functions as a solution of environmental degradation since the environment elements have been early considered in the policy

13 Riant Nugroho Dwijowijoto, 2003, Kebijakan Publik Formulasi, Implementasi, dan Evaluasi, Jakarta: PT. Elex Media Komputindo, p. 183.

14 Endang Sutrisno, "Role of law in Construction and Development of Small Scale Industries Through Normative Perspective",Jurnal Dinamika Hukum, Vol. 15 No. 3, September 2015, p. 319. formulation stage. According to Friedman, law as the regulation has legal effects to human attitude which are classified into compliance, deviance, and evasion. ${ }^{15}$ The norm of Strategic Environmental Assessment must be obeyed as it is explained in form of policy in order to create the justice even it should be studied by theoritical and philosophical point of view. ${ }^{16}$ The law is fulfilled by value and idea to build a new culture which is more contextual to the sense of social justice. ${ }^{17}$

Based on the research conducted by Development Planning Agency at Sub-National Level (Bappeda) and Environmental Agency of Cirebon City, there are empirical data that Cirebon has not owned documents of Strategic Environmental Assessment yet especially policies which rule the management of coastal area development. ${ }^{18}$ It is based on legal provisions of Cirebon City's plan in formulating Coastal Zone and Small Island Zoning Policy Year 2013. Yet, due to many factors including lack of human resources, institutional and budgetary constraints cause those policies have not been ratified by the government. ${ }^{19}$ Meanwhile, other empirical data related to environmental issues for concern are: first, environmental pollution control includes water pollution control (ground and surface water), air pollution and noise pollution controls.

Second, the control of environmental damage includes controls of coastal erosion, abrasion, and accretion; controls of depletion and seawater intrusion; Management and rehabilitation of coastal marine ecosystems; the decrease

15 Mella Ismelina Farma Rahayu, "Keadilan Ekologis dalam Gugatan Class Action Tempat Pembuangan Akhir Leuwigajah (Kajian Putusan Nomor 145/Pdt.G/2005/PN. Bdg)", Jurnal Yudisial, Vol. V No. 01. April 2012, p. 27.

16 Bahder Johan Nasution, "Kajian Filosofis tentang Konsep Keadilan dari Pemikiran Klasik sampai Pemikiran Modern", Jurnal Hukum Yustisia, Ed. 89, May-August 2014, p. 119.

17 A. Sukris Sarmadi, "Membebaskan Positivisme Hukum ke Ranah Hukum Progresif (Studi Pembacaan Teks Hukum bagi Penegak Hukum)", Jurnal Dinamika Hukum, Vol. 12 No. 2, May 2012, p. 335.

18 Interview Result with Physical and Environmental Department of Bappeda Kota Cirebon on February $18^{\text {th }}$, 2015.

19 Interview with Kasi Konservasi dan Pemulihan Kantor Lingkungan Hidup on April $7^{\text {th }}, 2015$. 
of supporting capacity and accommodating capacity of environment.

Third, the countermeasures of climate change impacts. Climate change is a natural phenomenon that gives impact to the increaseingly vulnerable Cirebon City which topographically consists of coastal area and lowland. Besides, climate change will increase the potential and the possibility of extreme climate and hydrometrological disaster like tidal flood. Furthermore, another impact of climate change will affect condition of poverty in urban area especially in coastal area. Therefore, adapation is needed to increase community's endurance in facing climate change. The realization is done through upgrading the quality of institution, human resources, and governance which includes upgrading the capacity and the readiness of government and society, data and information development related to climate condition, and the redesign of all aspects of development program. Hence, it would be adaptive and responsive toward the climate change.

Fourth, disaster countermeasures. Many disasters could possibly haunt Cirebon City. Those potential disasters are flood (including tidal and inundation), land slide, fallen trees and fires. It notably takes a mitigation disaster upgrading in coastal area of Cirebon City. Those policies made by government will bring important impacts to coastal area people. Besides, those policies must be balanced by people's participation to help government make assessment and useful policies for people interest in Cirebon coastal area.

Legal Problems in Perspective of Strategic Enviromental Assessment of Cirebon City Coastal Area

Legal problems that occur with the issue of Strategic Enviromental Assessment for the sustainable development of Cirebon City's coastal area, namely the policy, plan or government program have been determined to be irrelevant and even cause concern for the impact of policy, plan or program. This condition should be every one's concern between stakeholders in the region considering that underlies the en- forcement of norms, the Strategic Enviromental Assessment has been explicitly regulated in the legal rules of Law Number 32 Year 2009 on Preservation and Management of Environment, Regulation of the Minister of Home Affairs Number 67 Year 2012 on Guidelines for Implementation of Strategic Enviromental Assessment in the Preparation or Evaluation of Regional Development Plans, Law Number 1 Year 2014 on Amendment to Law Number 27 Year 2007 on Coastal Management and Small Islands. In addition, it should also take into account the legal norms that will be associated with the regulation of Strategic Environmental Assessment in the area of the Regional Regulation of Cirebon City Number 7 Year 2013 on Regional Medium Term Development Plan Cirebon City Year 20132018, Regional Regulation Cirebon City Number 8 Year 2012 on Regional Spatial Planning of Cirebon 2011-2031.

The potential impacts if the documents of Strategic Environmental Assessment are not made by Cirebon City Government especially for the sustainable development of Cirebon City's coastal include: first, economy. Most economic activities generated from the coastal areas are from fishery products sale. Areas that are not supported by the development of strong rules and alternative policy will get impact on the income of fishermen and fish entrepreneurs. It can reduce the selling value of the fish itself. Moreover, it can even reduce the market share of the coastal economy of Cirebon City.

Second, spatial. Placement and development should be based on the physical condition, potentials, and function since the city requires to be developed. The unmanaged and unmaintained environment causes environmental damage, environmental pollution from waste production.

Third, law enforcement. Lack of communication between policy makers, especially Development Planning Agency at Sub-National Level and Cirebon City Environmental Aggency will affect every policy that will be formulated partcularly related to the policy of application for development of Cirebon City's coastal area. 
The ineffectiveness of various environmental management instruments, especially regulation enforcement on spatial planning and environmental impact analysis is an important consideration for putting the strategy of adoption and implementation of Strategic Environmental Assessment in Indonesia, especially in Cirebon City. This law enforcement as a process to realize legal wishes should have been materialized, to build sustainably coastal management, and to improve the coastal communities welfare as one of the coastal stakeholders. This means that the concern for the values needed for coastal communities and the coastal environment is aimed to reach the welfare of marginalized fishermen through siding on coastal environmental development issues that focus on sustainability, harmony, and equilibrium values, integrity, benefit, careful, participation by regarding the values of local wisdom and justice not only to citizens but also to the environment.

\section{Conclusion}

Cirebon City does not have documents of Strategic Environmental Assessement, especially policy in coastal area development management. This is caused by various factors including inadequate human resources, limited institutional strengthening and lack of budget from the government. It affects the policy which is not legalized by the government.

Legal problems that occur with Strategic Environmental Assessment can affect the aspects of economic, spatial, environment and law enforcement in Cirebon City. Therefore, it is automatically mandatory for the government to make a Strategic Environmental Assessment to balance the policies that affect the environment in order to lead to the concept of sustainable development.

\section{Suggestion}

The Local Government of Cirebon City must establish a Strategic Environmental Assessment policy. It is crucial in the development of Environmental Law norms as part of stakeholder alignments in the region in ensuring the function of the Strategic Environmental Assessment documents as the evidence that the principle of sustainable development has become the basis and it has been integrated for development in the area, as mandated by Article 15, Article 16, Article 17 and Article 18 of Law Number 32 Year 2009 on Preservation and Management of Environment. In the end, the Local Government of Cirebon City must formulate legal products of the Regional Regulation on Strategic Environmental Assessment, considering the importance of the content of Strategic Environmental Assessment related to supporting capacity and accommodating capacity of environment for the development.

\section{References}

Artadi, Ibnu. "Dekonstruksi Pemahaman Penyelesaian Sengketa Bisnis (Ekonomi dan Keuangan) Beraspek Pidana melalui Prosedur Perdamaian: Menuju Proses Peradilan Pidana Rekonsiliatif". Jurnal Hukum Responsif. Vol. 1 No. 1. 2011. Pp. 22-34;

Atmasasmita, Romli."Tiga Paradigma Hukum dalam Pembangunan Nasional”. Jurnal Hukum Prioris. Vol. 3 No.1. 2012. Pp. 1-26;

Bureni, Yunus. "Moralitas Pembentukan Peraturan Daerah dalam Upaya Mencapai Keadilan Substantif (Morality Formation of Local Regulations in An Effort to Ensure Substantive Justice)". Jurnal Legislasi Indonesia. Vol. 10 No. 2. June 2013. Pp. 123131;

Dayanto. "Rekonstruksi Paradigma Pembangunan Negara Hukum Indonesia Berbasis Pancasila". Jurnal Dinamika Hukum. Vol. 13 No. 3. September 2013. Pp.498-509. DOI: 10.20884/1.jdh. 2013.13.3.253;

Dwijowijoto, Riant Nugroho. 2003. Kebijakan Publik Formulasi. Implementasi. dan Evaluasi. Jakarta: PT. Elex Media Komputindo;

Ibrahim, Johnny. 2006. Teori dan Metodologi Penelitian Hukum Normatif. Malang: Bayumedia Publishing;

Nasution, Bahder Johan. "Kajian Filosofis tentang Konsep Keadilan dari Pemikiran Klasik sampai Pemikiran Modern". Jurnal Hukum Yustisia. Ed.89. May-August 2014. Pp. 118-130. DOI: 10.20961/yustisia.v3i2. 11106;

Prentha, Bahria. "Filsafat Hukum dan Nilai-Nilai Pancasila”. Jurnal Ilmiah Kebijakan Hu- 
kum. Vol. 5 No. 2. August 2011. Pp. 175194;

Rahayu, Mella Ismelina Farma. "Keadilan Ekologis dalam Gugatan Class Action Tempat Pembuangan Akhir Leuwigajah (Kajian Putusan Nomor 145/Pdt.G/2005/PN.Bdg)". Jurnal Yudisial. Vol. V No. 01. April 2012. Pp. 13-35;

Sarmadi, A Sukris. "Membebaskan Positivisme Hukum ke Ranah Hukum Progresif (Studi Pembacaan Teks Hukum bagi Penegak Hukum)". Jurnal Dinamika Hukum. Vol. 12 No. 2. May 2012. Pp. 331-343. DOI: 10. 20884/1.jdh.2012.12.2.58;

Sutrisno, Endang and Sudarminto. "Legal Culture of Fisherman Communities in Indonesia (Studies in Cirebon Coastal Fishing Communities in the Northern Coast of West Java. Indonesia)". International Journal of Current Advanced Research. Vol. 6 Issue 2. February 2017. Pp. 22492253;

Sutrisno, Endang. "Implementasi Pengelolaan Sumberdaya Pesisir Berbasis Pengelolaan Wilayah Pesisir Secara Terpadu Untuk Kesejahteraan Nelayan". Jurnal Dinamika Hukum. Vol. 14 No.1. 2014. Pp. 1-12. DOI: 10.20884/1.jdh.2014.14.1.272;

Sutrisno, Endang. "Role of law in construction and development of small scale industries through normative perspective".Journal of Dinamika Hukum. Vol. 15 No. 3. September 2015. Pp. 317-323. DOI: 10. 20884/1.jdh.2015.15.3.411;

Sutrisno, Endang. "Tracing the Performance of Law in Indonesia (A Perspective of Thomas Kuhn's "Normal Science". Journal of Law. Policy and Globalization. Vol. 37. 2015. Pp.126-137;

Sutrisno, Endang. Esmi Warassih. "Harmonization of Fisheries Law for Fishermen Empowerment in Indonesia". South East Asia Journal of Contemporary Business. Economics and Law. Vol.11. Issue 4 December 2016. Pp. 45-51;

Yasin, Rahman. "Telaah Putusan MK dalam Sengketa PHPU Pilpres 2004 (Perspektif Negara Demokrasi Konstitusional)". Jurnal Konstitusi. Vol. 11 No. 4. December 2014. Pp. 650-670. 